\title{
Severe malnutrition is associated with decreased levels of plasma transferrin receptor
}

\author{
BY FRANCIS O. T. AKENAMI ${ }^{1,2,4} *$, ANTTI VAHERI ${ }^{1}$, MARJALEENA KOSKINIEMI ${ }^{1}$, \\ SANNA-MARIA KIVIVUORI ${ }^{2}$, EMMANUEL E. EKANEM ${ }^{3}$, DEBAYO M. BOLARIN $^{4}$ \\ AND MARTTI A. SIIMES ${ }^{2}$ \\ ${ }^{1}$ Department of Virology, University of Helsinki, Finland \\ ${ }^{2}$ Children's Hospital, University of Helsinki, Finland \\ ${ }^{3}$ Department of Paediatrics, University of Calabar, Nigeria \\ ${ }^{4}$ Department of Chemical Pathology, University of Calabar, Nigeria
}

(Received 30 October 1995 - Revised 20 June 1996 - Accepted 9 August 1996)

\begin{abstract}
Sixty children aged 1-3 years with protein malnutrition were involved in the present study. Measurements were made of plasma transferrin receptor (TfR), haemoglobin (Hb), ferritin, transferrin and $\mathrm{Fe}$ in comparison with twenty apparently healthy age- and sex-matched reference children in Nigeria. Plasma TfR was measured by an immunofluorometric assay. The mean plasma concentrations of both albumin $(37 \mathrm{~g} / 1)$ and transferrin $(1.88 \mathrm{~g} /)$ were within reference ranges in the 'healthy' children. The malnourished children had severe protein deficiency as indicated by their significantly lower mean plasma albumin (24.4-28.2 g/; $P<0.0001)$ and transferrin (1.24-1.53 g/l; $P<0.0001)$ concentrations in comparison with the reference children. In the reference children, the traditional indicators of $\mathrm{Fe}$ nutrition (plasma $\mathrm{Fe}$, transferrin $\mathrm{Fe}$ saturation and $\mathrm{Hb}$ ) were within the reference ranges, but ferritin values were raised, indicating acute or chronic infection and/or inflammation. The mean concentrations of plasma TfR $(4 \cdot 2-5.2 \mathrm{mg} / \mathrm{l})$ in the malnourished group were significantly lower than the mean $(6 \cdot 1 \mathrm{mg} /)$ of the reference children $(P=0 \cdot 0009)$. In the children with severe malnutrition, none of the indicators of Fe status except $\mathrm{Hb}(81 \cdot 5-86 \cdot 7 \mathrm{~g} / \mathrm{l}$; $P<0 \cdot 0001)$ showed Fe deficiency, including the serum concentration of TfR and the TfR : ferritin ratio, although the Fe status was lower than in the reference children (for $\mathrm{Fe} P=0.009$; and ferritin $P=0.0004)$. In the absence of haemodilution, the low $\mathrm{Hb}$ values are a clear indication that the malnourished children were Fe deficient; none of the other indices was indicative of Fe deficiency. This is the first report of TfR levels in malnourished and healthy African children.
\end{abstract}

Transferrin: Ferritin: Iron: Malnutrition

Despite our extensive knowledge of Fe metabolism, diagnosis of Fe deficiency often remains a difficult problem. Mild Fe deficiency is difficult to diagnose, whatever methods are used. Moreover, even the diagnosis of severe Fe deficiency is complicated, especially in patients with protein malnutrition. Evaluation of Fe stores would be of clinical benefit; however, reliable results can be obtained only by invasive techniques (Skikne et al. 1990). Serum transferrin receptor (TfR) is a new measure that reflects the Fe status and the rate of erythropoiesis in adults (Kohgo et al. 1986, 1987; Flowers et al. 1989; Huebers et al. 1990; Skikne et al. 1990; Beguin, 1993). According to Skikne et al. (1990), tissue Fe requirements are more important determinants of the serum TfR level than increases in erythropoiesis. The amount of the receptor increases soon after signs of Fe deficiency appear, the rise reflecting the paucity of available tissue Fe. In advanced Fe deficiency, the mean

*For reprints. 
serum TfR concentration increases to approximately three times the normal mean (Ferguson et al. 1992).

The serum TfR concentration has been measured in healthy children and adults (Flowers et al. 1989; Carriaga et al. 1991; Kivivuori et al. 1993; Kuvibidila et al. 1994). When erythropoiesis was stimulated in very-low-birth-weight infants and in children with acute lymphoblastic leukaemia, there was a rise in serum TfR level (Kivivuori et al. $1994 a, b)$. In these studies, the rise could be attributed to either stimulated erythropoiesis or lack of Fe. Measurements of the concentration of serum TfR may have several advantages over other tests used for the assessment of Fe nutrition. Although individuals with low serum ferritin concentrations have a higher risk of Fe deficiency (Hallberg et al. 1993) and those with high serum ferritin concentrations probably have sufficient Fe stores, most healthy subjects have intermediate values.

Unlike serum ferritin concentrations, serum TfR concentrations are thought not to be influenced by infections or chronic inflammation, which may be a great advantage (Ferguson et al. 1992; Nielsen et al. 1994; Petterson et al. 1994; Punnonen et al. 1994).

It has been suggested that anaemic patients with acute or chronic inflammatory diseases can be distinguished from those with Fe-deficiency anaemia by their low or normal serum TfR concentrations (Ferguson et al. 1992).

The aim of the present study was to evaluate the plasma concentrations of TfR in malnourished Nigerian children, who are usually at a greater risk of Fe deficiency than their healthy counterparts.

\section{SUBJECTS AND METHODS}

\section{Study population}

The procedures followed were in accord with the standards of the Ethical Committee of the University of Calabar, Nigeria, for human experimentation. Informed consent was obtained from the parents of the children. The malnourished children had clinical signs and symptoms of anaemia such as pallor of the skin and conjunctiva, fatigue and lack of appetite. The initial study population consisted of 206 malnourished and 200 reference children aged 1-3 years. After screening for antibodies to human immunodeficiency virus (HIV) and hepatitis B virus surface antigen (HBsAg), sixty patients were enrolled in the study, twenty from each category of malnutrition, and twenty apparently healthy age- and sex-matched Nigerian children from the HIV- and HBsAg-negative population. This selection was necessary both for laboratory safety and affordable cost of specimen analysis. The eighty subjects were randomly picked from the HIV-and HBsAg-negative population. The reference group had a mean age of 2.3 (SD 0.6) years and mean weight of 12.4 (SD 1.0) $\mathrm{kg}$. The malnourished consisted of kwashiorkor ( $n$ 20, mean age 2.2 (SD 0.6) years, mean weight 8.0 (SD 0.9) kg), marasmic kwashiorkor ( $n$ 20, mean age 2.2 (SD 0.6) years, mean weight 7.1 (SD 0.6) $\mathrm{kg}$ ), and marasmus ( $n$ 20, mean age 2.1 (SD 0.7) years, mean weight 6.9 (SD 0.7) kg. Protein-energy malnutrition (PEM) was diagnosed and subgrouped by the Wellcome classification (Editorial, 1970). We attempted to define severity of malnutrition by plasma albumin values using $30 \mathrm{~g} / \mathrm{l}$ as cut-off, and plasma ferritin values $\geq 100 \mu \mathrm{g} / \mathrm{l}$ for inflammation. Using these values, we arrived at the following distribution: plasma albumin $\geq 30 \mathrm{~g} / \mathrm{l}$, ferritin < $100 \mu \mathrm{g} / \mathrm{l}$ ( $n$ 12); albumin < $30 \mathrm{~g} / \mathrm{l}$, ferritin < $100 \mu \mathrm{g} / \mathrm{l}(n \mathrm{43})$; albumin $<30 \mathrm{~g} / 1$, ferritin $>100 \mu \mathrm{g} / \mathrm{l}(n \mathrm{4})$ and albumin $\geq 30 \mathrm{~g} / \mathrm{l}$, ferritin $>100 \mu \mathrm{g} / \mathrm{l}(n \mathrm{l})$. 


\section{Specimen collection}

The samples were collected from Calabar in the southeast, Warri in the Niger Delta, and Ibadan in the Southwestern area, all in the southern part of Nigeria. Blood (2.5-3.0 ml) was collected by venipuncture from each of the subjects in a non-fasting state. The sample was put into a citrated bijou bottle prepared by allowing $50 \mu \mathrm{l}$ of sodium citrate $(280 \mathrm{~g} / 1)$ to dry. Plasma samples were prepared by centrifuging the blood at about $500 \mathrm{~g}$ for $5 \mathrm{~min}$. Samples were stored at $-20^{\circ}$ until they were transported to Finland in solid $\mathrm{CO}_{2}$.

\section{Transferrin receptor assay}

TfR was assayed by the two-step sandwich-type time-resolved immunofluorimetric technique developed by one of us (Kivivuori et al. 1993). All the materials and techniques employed in this assay were the same as previously published (Kivivuori et al. 1993). Briefly, into wells in polystyrene plates coated with monoclonal antibody, $100 \mu \mathrm{l}$ of sample or standard was dispensed in duplicate, diluted in Delfia assay buffer solution (LKB Wallac, Turku, Finland) containing $65 \mathrm{~g}$ bovine serum albumin/l (Winlab, Leicester) to simulate the viscosity of serum; $100 \mu \mathrm{l}$ of assay buffer solution was added and the wells were incubated for $3 \mathrm{~h}$ at room temperature with continuous gentle shaking (Wallac Plate Shake 1296-001, LKB Wallac). The wells were washed three times with the washing solution and $100 \mathrm{ng}$ europium-labelled immunoglobulin $\mathrm{G}(\mathrm{IgG})$ in $200 \mu \mathrm{l}$ of the assay buffer was added. After further incubation for $2.5 \mathrm{~h}$ at room temperature with continuous gentle shaking, the wells were washed and $200 \mu$ l Delfia enhancement solution (LKB Wallac) was added. The wells were shaken gently and after $60 \mathrm{~min}$ the fluorescence was measured with a 1230 Arcus Fluorimeter (LKB Wallac) using a counting time of $1 \mathrm{~s}$ and a time delay of $400 \mu$ s (Soini \& Kojola, 1983). The concentration of TfR was read by comparison from a standard curve, constructed from values for a series of dilutions of a standardized serum pool with assay buffer containing $65 \mathrm{~g}$ bovine serum albumin/l. As controls we used two dilutions $(1: 50$ and $1: 100)$ of a serum pool containing $6.4 \mathrm{mg} \mathrm{TfR} / \mathrm{l}$. The inter-assay CV were 12.8 and $16.9 \%(n 6)$ and the intra-assay $C V$ were 11.4 and $8.2 \%$ (n 20) with 1:100 and 1:50 dilutions of the control pool respectively. When known amounts of TfR were added to the serum samples, a mean of $96.8 \%$ of the calculated value was recovered (CV $15.5 \%, n 33)$.

\section{Other methods}

Plasma albumin was estimated spectrophotometrically, using a dye-binding technique (bromo cresol green). The plasma Fe (Feren method, Orion Diagnostica, Espoo, Finland) and blood haemoglobin $(\mathrm{Hb})$ (cyanmethaemoglobin technique) concentrations were measured colorimetrically, and plasma transferrin by an immunoturbidimetric method (Anttila \& Siimes, 1996). Plasma ferritin was measured with a radioimmunoassay, using commercial reagents (Ferritin RIA Kit, Kodak Clinical Diagnostics, Amersham, Bucks.). For plasma ferritin assay, four controls with concentrations of 13, 55, 163 and $360 \mu \mathrm{g} / 1$ (obtained from Ciba-Corning Diagnostics Corp., Medfield, MA, USA) were used. These were standardized against the World Health Organization reference standard (WHO IRP $80 / 602$ ). The intra-assay $\mathrm{CV}$ were $2 \cdot 8,2 \cdot 6,2.7$ and $3.6 \%$ respectively, while the inter-assay $\mathrm{CV}$ were $5.0,6 \cdot 1,4.7$, and $5.1 \%$ respectively. The reference range for $\mathrm{Fe}$ deficiency (ferritin) is 1-35 $\mu \mathrm{g} / \mathrm{l}$. The transferrin Fe saturation (TIS) was calculated as the ratio of plasma Fe in $\mu \mathrm{mol} / /$ (multiplied by 100) to plasma transferrin in $\mathrm{g} / \mathrm{l}$ (multiplied by 20 ). The 
samples were screened for HIV antibodies (Enzygnost Kit, Behringwerke AG, Marburg, Germany), and for HBsAg (Murex Diagnostics, Dartford, Kent).

\section{Classification of malnutrition}

Within the spectrum of PEM most investigators have recognized three clinical types of severe malnutrition: kwashiorkor, marasmus and marasmic kwashiorkor. The criteria for distinguishing between these three conditions are still based mainly on clinical findings. This means that classification tends to be qualitative. We used the Wellcome classification, which is based on the presence or absence of oedema and the deficit in body weight. The 50th percentile Harvard Boston value was used as weight-for-age standard (Editorial, 1970).

(1) Kwashiorkor. These are children with oedema who weigh between 60 and $80 \%$ of their expected weight for age. It is also recognized, however, that there are some children with oedema and all the clinical features of kwashiorkor who should be so classified even though their body weight exceeds $80 \%$ of the standard weight for age.

(2) Marasmus. These are children without oedema who weigh less than $60 \%$ of their expected weight for age.

(3) Marasmic kwashiorkor. These are children with oedema who weigh less than $60 \%$ of their expected weight for age.

\section{Statistical methods}

Results are reported as means with their standard errors (SEM). ANOVA was used first to compare the malnourished children with the reference group. Second, ANOVA was used for each variable to compare the malnourished groups with each other. The error mean squares from these ANOVA were used in the calculation of pooled SEM for the malnourished groups. Correlation coefficients were evaluated according to Pearson. Results were considered significant when $P \leq 0.05$.

\section{RESULTS}

\section{Protein status}

The reference children had significantly higher concentrations of plasma albumin and transferrin than the malnourished children (Table 1).

\section{Iron status by traditional criteria}

Reference subjects. The traditional plasma variables for the assessment of $\mathrm{Fe}$ status indicated that in the reference population, Fe nutrition was sufficient. The mean values of blood $\mathrm{Hb}$, plasma $\mathrm{Fe}$, transferrin, ferritin and the TIS were consistent with the concentrations accepted for Fe adequacy.

Malnourished patients. Except low $\mathrm{Hb}$ levels, the traditional variables also showed adequate Fe nutrition in the malnourished subjects, although most of the mean values were lower than those of the reference subjects (Table 1). 
Table 1. Plasma concentrations of several biochemical variables in malnourished children and reference subjects

(Mean values with their standard errors for twenty children per group)

\begin{tabular}{|c|c|c|c|c|c|c|c|c|}
\hline \multirow[t]{2}{*}{ Group... } & \multicolumn{2}{|c|}{ Reference } & \multicolumn{2}{|c|}{ Kwashiorkor } & \multicolumn{2}{|c|}{$\begin{array}{c}\text { Marasmic } \\
\text { kwashiorkor }\end{array}$} & \multicolumn{2}{|c|}{ Marasmus } \\
\hline & Mean & SE & Mean & SE & Mean & $\mathrm{SE}$ & Mean & SE \\
\hline Albumin $(\mathrm{g} / \mathrm{l})$ & 37.0 & 1.0 & $24.4 * * *$ & 0.9 & $26 \cdot 5 * * *$ & 0.9 & $28.2 *$ & 0.9 \\
\hline Iron $(\mu \mathrm{mol} / \mathrm{l})$ & $15 \cdot 6$ & $1 \cdot 18$ & $11.7^{* *}$ & $1 \cdot 16$ & $11 \cdot 1^{* *}$ & $1 \cdot 16$ & $13 \cdot 2 * *$ & $1 \cdot 16$ \\
\hline Haemoglobin $(\mathrm{g} / \mathrm{l})$ & 133 & 3.7 & $82^{* * *}$ & $3 \cdot 2$ & $82 * * *$ & $3 \cdot 2$ & $87^{* * *}$ & $3 \cdot 2$ \\
\hline Transferrin $(\mathrm{g} / \mathrm{l})$ & 1.88 & 0.063 & $1 \cdot 24 * * *$ & 0.060 & $1 \cdot 32 * * *$ & 0.060 & $1.53 * * *$ & 0.060 \\
\hline TIS (\%) & 42 & 5.68 & $47^{*}$ & 5.67 & 42 & 5.67 & 43 & 5.67 \\
\hline Ferritin $(\mu g / 1)$ & 87 & $8 \cdot 18$ & $51 * * *$ & 6.98 & $62 * * *$ & 6.98 & $55 * * *$ & 6.98 \\
\hline $\operatorname{TfR}(\mathrm{mg} / \mathrm{l})$ & $6 \cdot 1$ & 0.44 & $4 \cdot 2^{* * *}$ & 0.43 & $3 \cdot 4 * * *$ & 0.43 & $5 \cdot 2 * *$ & 0.43 \\
\hline TfR:ferritin $(\mu \mathrm{g} / \mu \mathrm{g})$ & 79 & 8.4 & $114^{*}$ & 22 & 75 & 22 & $141 *$ & 22 \\
\hline
\end{tabular}

TIS, transferrin iron saturation; TfR, transferrin receptor.

Mean values were significantly different from those for the reference group: $* P<0.05, * * P<0.01, * * * P<0.001$. Comparison of means and significance tests were done using ANOVA. Pooled SEM for malnourished children were based on the error mean square from the ANOVA of the results for malnourished children.

\section{Transferrin receptor and transferrin receptor:ferritin ratio}

The mean concentration of plasma TfR in the reference children was higher than those of the malnourished children, but the reverse was the case with TfR : ferritin ratio.

In the malnourished children with plasma albumin $\geq 30 \mathrm{~g} / \mathrm{l}$ and ferritin $<100 \mu \mathrm{g} / \mathrm{l}(\mathrm{n}$ 12), the mean albumin concentration was 32 (SE 7) g/l, ferritin was 52 (SE 7.2) $\mu \mathrm{g} / \mathrm{l}$ and TfR was $4.0(\mathrm{SE} 0.28) \mathrm{mg} / \mathrm{l}$. However, in children with plasma albumin $<30 \mathrm{~g} / 1$ and ferritin $<100 \mu \mathrm{g} / 1(n 43)$, the mean albumin value was 25 (SE0.5) $\mathrm{g} / \mathrm{l}$, ferritin was 51 (SE 3.7) $\mu \mathrm{g} / \mathrm{l}$ and TfR was 4.0 (SE0.35) $\mathrm{mg} /$.

No significant differences were observed between malnourished groups with two exceptions. The mean plasma value of transferrin in marasmic patients was higher than those found in kwashiorkor $(P=0.002)$ and marasmic kwashiorkor patients $(P=0.03)$. Moreover, the mean plasma albumin value of marasmic patients was higher than that of kwashiorkor patients $(P=0.003)$.

\section{Relationship of plasma transferrin receptor to plasma albumin}

When plasma TfR or the TfR : ferritin ratio was plotted as a regression $v$. plasma albumin, no correlations were found in either the reference or the malnourished subjects.

\section{DISCUSSION}

We report here our findings in a study which involved sixty patients with PEM and twenty apparently healthy reference children in Nigeria. Although the plasma concentration of albumin, which is an indicator of protein status, was significantly higher in the reference population than those found in the patients, the mean concentrations fell within the low range for healthy children in developed countries. Differences in plasma concentrations of biochemical variables between tropical and temperate regions of the world abound, due to variations in diet and environment. However, our plasma albumin results for the patients 
indicate severe protein malnutrition, most severe in those with kwashiorkor and the least severe in those with marasmus (Hay et al. 1975).

To evaluate the Fe status of our subjects we employed the traditional criteria (blood $\mathrm{Hb}$, plasma $\mathrm{Fe}$, transferrin, TIS and ferritin) and also measured plasma TfR, which is a new indicator of Fe status (Kohgo et al. 1986, 1987; Flowers et al. 1989; Huebers et al. 1990; Skikne et al. 1990; Beguin et al. 1993). The traditional variables for the assessment of $\mathrm{Fe}$ status were within reference ranges in both the 'healthy' and malnourished children (Siimes et al. 1974; Saarinen and Siimes, 1979). The only exception was the low mean $\mathrm{Hb}$ values which indicated $\mathrm{Fe}$ deficiency in the malnourished population. The plasma TfR values for the reference children were higher than those reported for Finnish children (Kivivuori et al. 1993). There is no published information on the concentrations of serum TfR in apparently healthy African children. However, plasma TfR levels were significantly lower than in the reference children. Our data indicate adequate $\mathrm{Fe}$ and protein status in the reference children. These observations suggest that protein deficiency might affect the overall expression of TfR, and consequently depress circulating levels. An explanation might be that the hypoproteinaemia observed in the patients impairs both incorporation of $\mathrm{Fe}$ into $\mathrm{Hb}$ and the rate of erythropoiesis, which also determines the individual levels of serum TfR (Beguin et al. 1993; Kivivuori et al. 1994a,b). If this is the case, we would have expected to find some correlation between the levels of $\operatorname{TfR}$ and albumin. Moreover, a simple analysis using similar ferritin conditions and differing protein status did not reveal any difference in mean TfR values. This suggests that the protein status per se might not be the critical factor which determines the TfR values in malnutrition.

The lower levels of plasma TfR may be partly attributed to the dilutional effect of malnutrition. However, while it is true that the plasma volume is diluted in kwashiorkor patients (due to the markedly reduced value of plasma albumin which maintains the plasma oncotic pressure), this effect is minimal in marasmic kwashiorkor patients and absent in marasmic patients (Editorial, 1970).

While plasma ferritin values are not diagnostic in the presence of infections, it has been suggested that anaemic patients with acute or chronic inflammatory diseases can be distinguished from those with Fe-deficiency anaemia by their low or normal serum TfR concentrations (Ferguson et al. 1992). In the malnourished subjects, while the ferritin levels were higher than expected, the transferrin levels were lower than expected. This indicates inflammation and is capable of affecting the plasma TfR values. The relatively low plasma transferrin concentration encountered in the reference population, coupled with the elevated ferritin values, suggests that the reference population was not free of mild inflammation. Since we cannot rule out infection in the malnourished children, the presence of both a compromised Fe status and infection will tend to keep the serum TfR normal.

Anaemia of chronic inflammation (Ferguson et al. 1992), aplastic anaemia, chronic renal failure and marrow transplantation (Huebers $e t$ al. 1990) have been associated with decreased levels of plasma TfR; we should perhaps add severe tropical infantile protein malnutrition.

This study was supported by funds from the Nigerian National Universities Commission World Bank Assisted Staff Development programme, 1994, and the Medical Research Council of the Academy of Finland. The authors thank Dr James D. Cook, of Kansas University Medical Center, Kansas City, KS, USA who kindly supplied the monoclonal antibody and purified TfR. 


\section{REFERENCES}

Anttila, R. \& Siimes, M. A. (1996). Serum transferrin and ferritin in pubertal boys: relations to body growth, pubertal stage, erythropoiesis and iron deficiency. American Journal of Clinical Nutrition 63, $179-183$.

Beguin, Y., Clemons, G. K., Pootrakul, P. \& Fillet, G. (1993). Quantitative assessment of erythropoiesis and functional classification of anaemia based on measurements of serum transferrin receptor and erythropoietin. Blood 81, 1067-1076.

Carriaga, M. T., Skikne, B. S., Finley, B., Cutler, B. \& Cook, J. D. (1991). Serum transferrin receptor for the detection of iron deficiency in pregnancy. American Journal of Clinical Nutrition 54, 1077-1081.

Editorial (1970). Classification of infantile malnutrition. Lancet 2, 302.

Ferguson, B. J., Skikne, B. S., Simpson, K., Baynes, R. D. \& Cook, J. D. (1992). Serum transferrin receptor distinguishes anemia of chronic disease from iron deficiency anemia. Journal of Laboratory and Clinical Medicine 119, 385-390.

Flowers, C. H., Skikne, B. S., Covell, A. M. \& Cook, J. D. (1989). The clinical measurement of serum transferrin receptor. Journal of Laboratory and Clinical Medicine 114, 368-377.

Hallberg, L., Hulten, L., Lindstedt, G., Lundberg, P.-A., Mark, A., Purens, J., Svanberg, B. \& Swolin, B. (1993). Prevalence of iron deficiency in Swedish adolescents. Pediatric Research 34, 680-687.

Hay, R. W., Whitehead, R. G. \& Spicer, C. C. (1975). Serum-albumin as a prognostic indicator in oedematous malnutrition. Lancet 2, 427-429.

Huebers, H. A., Beguin, Y., Poottrakul, P., Einspahr, D. \& Finch, C. A. (1990). Intact transferrin receptors in human plasma and their relation to erythropoiesis. Blood 75, 102-107.

Kivivuori, S. M., Anttila, R., Viinikka, L., Pesonen, K. \& Siimes, M. A. (1993). Serum transferrin receptor for assessment of iron status in healthy prepubertal and early pubertal boys. Pediatric Research 34, $297-299$.

Kivivuori, S. M., Heikinheimo, M., Teppo, A. M. \& Siimes, M. A. (1994a). Early rise in serum concentration of transferrin receptor induced by recombinant human erythropoietin in very-low-birth-weight infants. Pediatric Research 36, 85-89.

Kivivuori, S. M., Viinikka, L., Teppo, A. M. \& Siimes, M. A. (1994b). Serum transferrin receptor and erythropoiesis in children with newly diagnosed acute lymphoblastic leukaemia. Leukaemia Research 18, 823-828.

Kohgo, Y., Niitsu, Y., Kondo, H., Kato, J., Tsushima, N., Sasaki, K., Hirayama, M., Numata, T., Nishisato, T. \& Urushizaki, I. (1987). Serum transferrin receptor as a new index of erythropoiesis. Blood 70, 1955-1958.

Kohgo, Y., Nishisato, T., Kondo, H., Tsushima, N., Niitsu, Y. \& Urushizaki, I. (1986). Circulating transferrin receptor in human serum. British Journal of Haematology 64, 277-281.

Kuvibidila, S., Yu, L. C., Ode, D. L., Warrier, R. P. \& Mbele, V. (1994). Assessment of iron status of Zairean women of childbearing age by serum transferrin receptor. American Journal of Clinical Nutrition 60, 603609.

Nielsen, O. J., Andersen, L. S., Hansen, N. E. \& Hansen, T. M. (1994). Serum transferrin receptor levels in anaemic patients with rheumatoid arthritis. Scandinavian Joumal of Clinical and Laboratory Investigation 54, $75-82$.

Petterson, T., Kivivuori, S. M. \& Siimes, M. A. (1994). Is serum transferrin receptor useful for detecting iron deficiency in anaemic patients with chronic inflammatory diseases? British Journal of Rheumatology 33, 740 744.

Punnonen, K., Irjala, K. \& Rajamäki, A. (1994). Iron-deficiency anaemia is associated with high concentrations of transferrin receptor in serum. Clinical Chemistry 40,774-776.

Saarinen, U. M. \& Siimes, M. A. (1979). Iron absorption from breast milk, cow's milk, and iron supplemented formula: an opportunistic use of changes in total body iron determined by haemoglobin, ferritin, and body weight in 132 infants. Pediatric Research 13, 143-147.

Siimes, M. A., Addiego, J. E. \& Dallman, P. R. (1974). Ferritin in serum: diagnosis of iron deficiency and iron overload in infants and children. Blood 43, 581-590.

Skikne, B. S., Flowers, C. H. \& Cook, J. D. (1990). Serum transferrin receptor: a quantitative measure of tissue iron deficiency. Blood 75, 1870-1876.

Soini, E. \& Kojola, H. (1983). Time-resolved fluorometer for lanthanide chelates: a new generation of nonisotopic immunoassays. Clinical Chemistry 29, 65-68. 